\title{
Paulo Freire perseguido: a pedagogia freireana na mira do Escola Sem Partido
}

\author{
Robson Lima de Arruda* - UEPB \\ Robéria Nádia Araújo Nascimento* - UFPB
}

\section{Resumo}

Criado em 2014, o movimento Escola Sem Partido ganhou força no contexto das eleições de 2018, quando a extrema direita ascendeu ao poder máximo do país. Dentre as bandeiras defendidas, está a acusação de "doutrinação ideológica" por parte dos professores e professoras, bem como a defesa da educação escolar "de acordo com as convicções da família". Aliado a políticos e grupos conservadores, os defensores do ESP intimidam docentes e atacam o educador Paulo Freire, negando seu legado para a educação brasileira. O presente artigo apresenta uma crítica ao ESP., com base nas obras Educação como Prática de Liberdade (1967), Pedagogia do Oprimido (1987) e Pedagogia da Autonomia (2018) e discute as diretrizes de uma pedagogia baseada no diálogo, na conscientização, liberdade, autonomia e mudança. Nota-se que o ESP. opera como representação da elite opressora, cujos privilégios assentam na permanência da alienação da classe oprimida.

Palavras-chave: Educação; Paulo Freire; Escola Sem Partido.

* Graduado em Pedagogia pela Universidade Estadual da Paraíba. É mestrando em Formação de Professores pela Universidade Estadual da Paraíba, Mestre em Psicanálise Aplicada à Saúde e Educação pela UNIDERC/ABEPE. Especialista em Psicanálise Aplicada à Educação e Saúde e Especialista em Educação Básica pelo Centro Universitário de João Pessoa, UNIPÊ. Integrante dos Grupos de Pesquisa Comunicação, Cultura e Desenvolvimento e Comunicação (DECOM/UEPB) e Tecnologias, Culturas e Linguagens (TECLIN/ UEPB). Atualmente é professor dos Anos Iniciais do Ensino Fundamental na rede municipal de ensino e Analista Educacional na rede Estadual, ambas em Vertente do Lério/PE. E-mail: robsonlima13@hotmail.com

** Orientadora da pesquisa. Doutora em Educação pela Universidade Federal da Paraíba-UFPB. Professora Associada da UEPB, Docente Permanente e Coordenadora Adjunta do Programa de Pós-Graduação em Formação de Professores (PPGFP/UEPB). E-mail: rnadia@terra.com.br 


\title{
Paulo Freire persecuted: Freire's pedagogy in the sights of School Without Party
}

\begin{abstract}
Created in 2014, the School Without Party movement gained strength in the context of the 2018 elections, when the extreme right rose to the maximum power of the country. Among the defended flags, there is the accusation of "ideological indoctrination" by teachers, as well as the defense of school education "according to the family's convictions". Allied with politicians and conservative groups, SWP. defenders intimidate teachers and attack educator Paulo Freire, denying his legacy for Brazilian education. This article presents a critique of ESP, based on the works Education as a Practice of Freedom (1967), Pedagogy of the Oppressed (1987) and Pedagogy of Autonomy (2018) and discusses the guidelines of a pedagogy based on dialogue, awareness, freedom , autonomy and change. It is noted that SWP operates as a representation of the oppressive elite, whose privileges are based on the permanence of the alienation of the oppressed class.
\end{abstract}

Keywords: Education; Paulo Freire; School Without Party.

\section{Paulo Freire perseguido: la pedagogía de Freire en la mira de la Escuela Sin Partido}

\section{Resumen}

Creado en 2014, el movimiento Escuela Sin Partido ganó impulso en el contexto de las elecciones de 2018, cuando la extrema derecha alcanzó el máximo poder del país. Entre las banderas defendidas, se encuentra la acusación de "adoctrinamiento ideológico" por parte de los maestros, así como la defensa de la educación escolar "de acuerdo con las convicciones de la familia". Aliados con políticos y grupos conservadores, los defensores de ESP intimidan a los maestros y atacan al educador Paulo Freire, negando su legado para la educación brasileña. Este artículo presenta una crítica de ESP, basada en las obras Educación como práctica de la libertad (1967), Pedagogía de los oprimidos (1987) y Pedagogía de la autonomía (2018) y discute las pautas de una pedagogía basada en el diálogo, la conciencia, la libertad, autonomía y cambio. Cabe señalar que ESP opera como una representación de la élite opresiva, cuyos privilegios se basan en la permanencia de la alienación de la clase oprimida.

Palabras llave: Educación; Paulo Freire; Escuela sin Partido. 


\section{Introdução}

O argumento de que professores doutrinam seus alunos é, no mínimo, polêmico e conflitante. Este tipo de afirmação precisa ser discutida com responsabilidade e coerência, tendo em vista que a história da educação no Brasil mostra que, pelo contrário, professores quase sempre utilizaram metodologias de ensino orientadas por ideologias políticas tradicionais e conservadoras.

No país, as teorias de perspectiva crítica tiveram início no século XX, a partir do movimento Escola Nova, que ganhou terreno no Brasil, depois de promulgada a Constituição de 1934. Antes disso, a nossa educação se dava sob forte influência da pedagogia tradicional, de orientação religiosa católica, e em seguida pela pedagogia tradicional leiga, inspirada no liberalismo clássico. Os anos 1980 marcaram o início de uma pedagogia que Demerval Saviani (2011) chamou de histórico-crítica. Nesta perspectiva, é necessário compreender "a educação no seu desenvolvimento histórico-objetivo e, por consequência, a possibilidade de se articular uma proposta pedagógica cujo ponto de referência, cujo compromisso, seja a transformação da sociedade e não a sua manutenção, a sua perpetuação" (SAVIANI, 2011, p.80).

A implantação dos diferentes modelos de ensino adotados, desde o início da educação formal brasileira, estava associada aos interesses da classe dominante, cujas políticas de popularização da educação configuravam mecanismos de alienação e de controle. Com isso, "a instrução generalizada da população contraria os interesses de estratificação das classes, ocorre essa tentativa de desvalorização da escola, cujo objetivo é reduzir o seu impacto e relação às exigências de transformação da própria sociedade" (SAVIANI, 2011, p.84). Um dos pensamentos que melhor representa esses interesses é atribuído por Karl Marx (1818-1883) a Adam Smith (1723-1790) quando recomendou "o ensino popular, a cargo do Estado, embora em doses cautelosamente homeopáticas" (MARX, 2011, p.542).

Disso extraímos que democratizar o acesso da população à educação configura uma das estratégias para manter a massa aliena- 
da sob o controle da elite e do Estado. Contudo, com esse acesso cada vez mais ampliado entre as classes populares e com o surgimento de tendências educacionais cada vez mais progressistas, foi necessário desenvolver outras estratégias para perpetuação da alienação e manutenção do status quo como, por exemplo, o controle sobre o currículo escolar.

O caráter político e ideológico está implícito em nossa educação desde a catequese dos povos indígenas, realizada pelos Jesuítas por volta de 1540 até 1759 , considerada a primeira prática de educação formal do país. Durante muito tempo a educação brasileira foi feita de cima para baixo e de fora para dentro, negando o aprendente e sua história de vida, considerado como alguém que precisava ser ensinado, instruído ou doutrinado.

O direito à educação como prerrogativa do Estado, por meio da Constituição Federal (BRASIL, 1988) é, ao mesmo tempo em que uma conquista social e democrática, um instrumento que pode ser utilizado pelo poder público para manutenção de suas ideologias de controle. Ainda que a atual Constituição seja considerada a mais democrática das que já foram implantadas no país, é possível que grupos políticos conservadores pleiteiem a utilização desta ferramenta do Estado Democrático de Direito em favor dos seus "princípios". É o caso do Movimento Escola Sem Partido que se ancora em Artigos da Constituição Federal e da Lei de Diretrizes de Bases da Educação Nacional para defender um anteprojeto intitulado Escola Sem Partido ${ }^{1}$.

$\mathrm{Na}$ contramão de uma educação libertadora e humanizada, o Projeto Escola Sem Partido, inscrito pela Lei No 867/2015, propõe, entre outros pontos, coibir o que eles chamam de "doutrina-

Quando falamos em Movimento Escola Sem Partido nos referimos às pautas e ações defendidas em campanhas e articuladas entre partidos e líderes políticos, religiosos e organizações, e ao citarmos Projeto Escola Sem Partido nos referimos ao Projeto de Lei no867/2015 e 193/2016 enviados ao Congresso Nacional e Senado Federal, respectivamente. Entretanto, o PL no Senado foi arquivado enquanto no Congresso um novo PL foi proposto em 2019 (PL 246/19). 
ção ideológica" por parte dos professores e garantir que a educação escolar esteja de acordo com as convicções da família. Este estudo pretende analisar e discorrer sobre algumas contradições que o Movimento Escola Sem Partido apresenta, tanto no tocante à ideia de "liberdade" e "neutralidade" descritas no projeto de Lei, quanto às críticas proferidas ao legado de Paulo Freire. Para isso, utilizamos as obras Educação como Prática de Liberdade (1967), Pedagogia do Oprimido (1987) e Pedagogia da Autonomia (2018). Tal escolha se deu em função de que estes escritos trazem conceitos fundamentais acerca da pedagogia freireana e apresentam pontos congruentes para contrapor a ideologia do projeto Escola Sem Partido.

\section{O que diz o Movimento Escola Sem Partido}

O anteprojeto Escola Sem Partido faz parte de um movimento iniciado em 2014, pelo advogado Miguel Nagib que, ao assumir representação de alguns pais e estudantes, defendeu o fim do que chamou de "doutrinação ideológica" por parte dos professores. Em 2015, o projeto ganhou notoriedade e se espalhou por diversas câmaras municipais e assembleias até chegar ao Congresso Nacional, através do PL n867/2015 e no Senado Federal através do PL no 193/2016. Dizem os projetos ${ }^{2}$ :

É fato e notório que professores e autores de livros didáticos vêm-se utilizando de suas aulas e de suas obras para tentar obter a adesão dos estudantes e determinadas correntes políticas e ideológicas; e para fazer com que eles adotem padrões de julgamento e de conduta moral- especialmente moral e sexual - incompatíveis com os que lhes são ensinados por seus pais ou responsáveis (PL 867/2015; PL 193/2016).

$\mathrm{Na}$ prática, os idealizadores do projeto Escola Sem Partido pretendiam fixar um cartaz com os "deveres do professor" nas salas de aula com o "objetivo de informar os estudantes sobre o

2 O teor dos projetos de Lei nº67/2015 e do PL n 193/2016 é basicamente o mesmo, inclusive com reprodução, não somente do título, mas de praticamente todo o texto que os compõem. 
direito que eles têm de não serem doutrinados"’3. No entanto, as medidas e consequências pretendidas pelo Escola Sem Partido vão além da fixação de um cartaz. Entre os princípios abordados no Projeto destacamos:

A neutralidade política, ideológica e religiosa do Estado; o pluralismo de ideias no ambiente acadêmico; liberdade de aprender; liberdade de crença; reconhecimento da vulnerabilidade do aluno como parte mais fraca na relação de aprendizado; direito dos pais a que seus filhos recebam a educação moral que esteja de acordo com suas próprias convicções (PL 867/2015; PL 193/2016).

Ironicamente, as premissas que sustentam o PL Escola Sem Partido parecem dialogar com os princípios básicos garantidos na Constituição Federal e na Lei de Diretrizes e Bases da Educação Nacional, LDB n 9.394/96, porém se não forem analisadas com cautela, responsabilidade e conhecimento sobre educação, podem fazer com que seu caráter hegemônico, conservador e antidemocrático, passem por despercebido.

Uma das principais pautas do PL Escola Sem Partido diz respeito ao argumento de que a educação é prerrogativa da família e da igreja e à escola caberia apenas o ensino. Baseado nisso, reivindicam o que chamam de "prevenção da doutrinação política e usurpação do direito dos pais a que seus filhos recebam a educação religiosa e moral que esteja de acordo com as suas próprias convicções"4.

O artigo 229 da Constituição Federal (BRASIL, 1988), que assegura aos pais "o dever de assistir, criar e educar os filhos", também é utilizado para reforçar esses argumentos, mas a própria Constituição, no Artigo 227, diz que é dever da família, da sociedade e do Estado assegurar à criança, entre outras coisas, o direito à

ESCOLA sem Partido: entenda o que é movimento que divide opiniões na Educação. Portal EBC. Brasil, 20 de julho de 2016. Disponível em: < https://www.ebc.com.br/educacao/2016/07/o-que-e-o-escola-sem-partido> Acesso em: 15 de abril de 2020.

4 Disponível em:<https://www.programaescolasempartido.org/faq> Acesso em: 18 de abril de 2020 . 
educação. No tocante às garantias e responsabilidades com a educação, é pertinente fazermos distinção entre educação familiar e escolar. O Art. 208 da Constituição Federal, por exemplo, dedica-se às garantias do Estado com a educação e tais direitos e deveres se estendem de forma sistemática por outros artigos e parágrafos do documento. Logo, ao falarmos em educação escolar, nos referimos aos saberes metódicos, sistemáticos, científicos, elaborados predominantemente sobre as outras formas de educação consideradas espontâneas, assistemáticas e "naturais" (SAVIANI, 2011).

Na tentativa da aprovação do PL No 867/2015, o Movimento Escola Sem Partido mobilizou discussões acerca de temas controversos e polêmicos como religiosidade, gênero e sexualidade, política e democracia. A menção ao tema da orientação sexual e ideologia de gênero, especificamente no PL 193/2016, inflamou ainda mais o debate, sobretudo no contexto das eleições de 2018, quando partidos e apoiadores da extrema direita espalharam notícias falsas sobre a suposta distribuição de Kit Gay e mamadeira de piroca em escolas do país. Políticos conservadores, grupos de apoiadores como o Movimento Brasil Livre (MBL), Revoltados Online, fundamentalistas religiosos, entre outros, foram responsáveis por popularizar esse tipo de informação utilizando, principalmente, as redes sociais como veículo de disseminação.

Em meio a este cenário de propagação da ideologia conservadora, amparada pelas fake news, cujo desfecho se dá pela chegada da extrema direita ao poder máximo do país, um importante personagem de nossa história educacional ganhou destaque, para além do âmbito acadêmico e educacional - onde já é reconhecido. Aqui, não por sua obra ou pela importância que tem, mas acusado de

Vídeos, fotos e textos foram espalhados em diversas redes sociais, durante o período das eleições de 2018, acusando o candidato Fernando Haddad do PT de distribuir mamadeiras com o bico em formato de pênis para creches do país como parte de um "kit gay" para crianças de 6 anos. O STE solicitou a remoção dos vídeos por conter injúrias e inverdades. Disponível em: < https://www.pragmatismopolitico.com.br/2018/10/mamadeira-erotica-de-haddad-fake-news.html> 
ser a referência de uma suposta doutrinação marxista, comunista e esquerdista no Brasil, Paulo Freire é praguejado. Nesta perspectiva - conforme os autores do Escola Sem Partido - Paulo Freire se tornou o símbolo do que deveríamos abominar enquanto pensamento político e pedagógico. O coordenador do Escola Sem Partido, Miguel Nagib afirma:

O que a gente defende é que alguns dos ensinamentos de Paulo Freire se chocam com a Constituição. Nossa crítica é de natureza jurídica, porque o uso da sala de aula para efeito de transformação da sociedade, como ele defendia, dependendo da maneira com que isso é aplicado, viola a liberdade dos alunos e a neutralidade política e ideológica do Estado (NAGIB, 2017).

Observamos, neste discurso, a tentativa de desvirtuar o verdadeiro sentido da pedagogia freireana por traz de um discurso que se pretende categórico. Esse tipo de afirmação, quando difundido de forma massificada, se transforma em uma pós-verdade ${ }^{6}$, quando "o critério da verdade é abandonado em favor de rumores e opiniões que ajudam na difusão de inverdades e na organização das forças sociais com base em suposições” (FRIGOT'TO, 2017, p.9). Nas redes sociais, essas inverdades são reproduzidas, curtidas e compartilhadas, sobretudo por quem não conhece a obra de Paulo Freire.

A propósito da situação do projeto ESP em todo país, cabe mencionar o movimento Professores Contra o Escola Sem Partido, uma iniciativa liderada por estudantes e professores com o objetivo de defender uma escola plural e democrática por meio da liberdade de expressão e autonomia docente.

Segundo levantamento ${ }^{7}$ feito pelo movimento Professores Contra o Escola Sem Partido, desde o lançamento do projeto, em 2015,

A pós-verdade se apresenta como mais verdadeiro do que a própria verdade. Baseia-se no apelo às emoções e crenças pessoais como sobreposição aos fatos. Atualmente, têm sido bastante evidenciadas a partir das redes sociais com a propagação de fake news que interferem no processo de apreensão da realidade cultural, educacional, política, de saúde e outras áreas sociais.

7 Disponível em: <https://www.escolasemmordaca.org.br/?page_id=4218> Acesso em: 28 de junho de 2020. 
até o segundo semestre de 2019, 208 propostas do ESP haviam sido apresentadas em Câmaras Municipais e Estaduais. Cumpre destacar que a maioria desses projetos (176) corresponde à esfera municipal. As regiões com maior adesão ao Escola Sem Partido foram a região Sudeste (75), Sul (55) e Nordeste (49), com destaque para o número elevado de propostas apresentadas no Estado de São Paulo (33), Paraná (25) e Rio de Janeiro (20). Ainda, de acordo com esses dados, até o fechamento deste artigo, em junho de 2020, 57 projetos estavam em tramitação, 41 haviam sido arquivados e 40 haviam entrado em vigor. O gráfico 1 mostra a situação dos projetos por regiões do país.

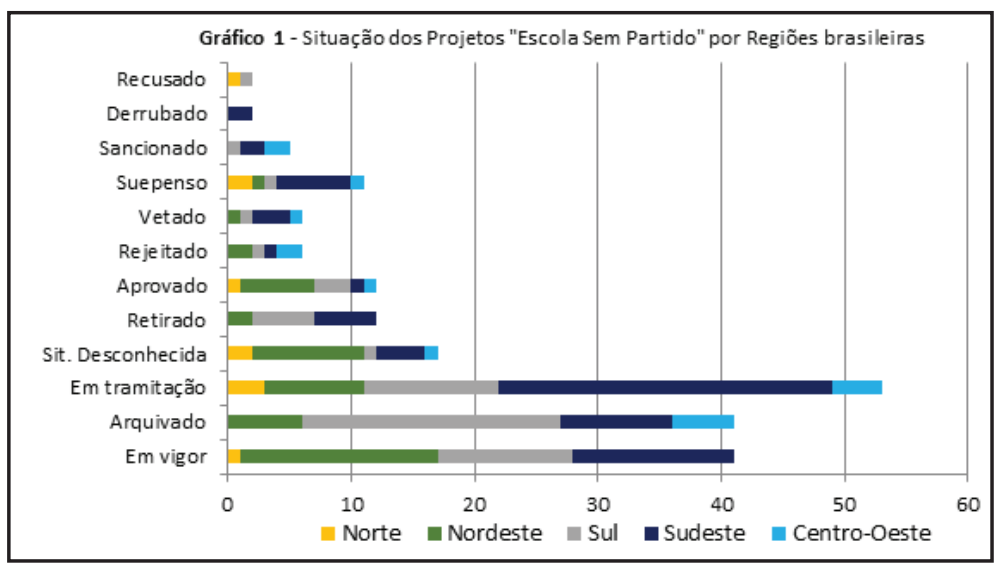

Fonte: Professores Contra o Escola Sem Partido. Elaboração: Os autores

\section{Lei da mordaça e inconstitucionalidade}

Nas entrelinhas do Projeto Escola Sem Partido, acham-se evidentes os interesses de impor o que seus próprios defensores afirmam combater: a doutrinação ideológica. Mas a Constituição Federal é clara, em seu Art. 206, ao assegurar que o ensino será ministrado seguindo, entre outros, os princípios de "liberdade de aprender, ensinar, pesquisar e divulgar o pensamento, a arte e o saber; pluralismo de ideias e de concepções pedagógicas" (BRASIL, 1988). A Lei de Diretrizes e Bases da Educação Nacional, Lei n 9.394/96 também reafirma, em seu Art. $3^{\circ}$, estes dispositivos já 
mencionados pela Constituição. Esses exemplos servem para ilustrar as garantias já asseguradas e evidenciar a forma contraditória que o Projeto ESP se utiliza delas para impor o que especialistas em educação afirmam se tratar de "lei da mordaça".

Apesar de mencionar termos como "neutralidade política, ideológica e religiosa", "pluralismo de ideias no ambiente acadêmico" e "liberdade de crença", o Projeto ESP apresenta textos como "reconhecimento da vulnerabilidade do educando como parte mais fraca em relação ao aprendizado" e "direito dos pais que seus filhos recebam a educação moral que esteja de acordo com suas próprias convicções", ideias claramente postas para justificar a "mordaça" (PL 867/2015; PL 193/2016, grifos nossos). O Art. $3^{\circ}$ do PL 867/2015 reafirma que as atividades que estejam em conflito com as convicções religiosas ou morais dos pais ou responsáveis devem ser vedadas. No Art. $4^{\circ}$ destaca-se a proibição do professor em fazer propaganda eleitoral em sala de aula, incitar manifestações, atos públicos e passeatas. E ao tratar de questões políticas, socioculturais e econômicas, orienta que deve o professor apresentar de forma justa, as principais versões, teorias, opiniões e perspectivas a respeito (PL 867/2015). A versão do ESP enviada ao Senado Federal acrescenta ainda que:

O Poder Público não se imiscuirá da opção sexual dos alunos nem permitirá qualquer prática capaz de comprometer, precipitar ou direcionar o natural amadurecimento e desenvolvimento de sua personalidade, em harmonia com a respectiva identidade biológica de sexo, sendo vedada, especialmente, a aplicação dos postulados da teoria ou ideologia de gênero (PL 193/2016, p.1-2).

Como podemos notar, os termos neutralidade, pluralismo e liberdade são antagônicos à proposta que visa atender às convicções morais, religiosas e políticas de determinado grupo social específico. Com isso, ela fere o princípio de isonomia e impessoalidade, previstos na Constituição Federal. Pensar em um ensino que atenda às convicções dos pais é, no mínimo, incoerente e desa- 
certado, considerando que tais convicções são repletas de crenças ideológicas particulares e que, por isso mesmo, não caberia à escola atender a tais especificidades já que ela deve ser plural.

Para Frigotto (2016), não se trata de escola sem partido e sim, de um partido único e absoluto:

partido da intolerância com as diferentes ou antagônicas visões de mundo, de conhecimento, de educação, de justiça, de liberdade; partido, portanto da xenofobia nas suas diferentes facetas: de gênero, de etnia, da pobreza e dos pobres, etc. Um partido, portanto que ameaça os fundamentos da liberdade e da democracia liberal, mesmo que nos seus marcos limitados e mais formais que reais. Um partido que dissemina o ódio, a intolerância e, no limite, conduz à eliminação do diferente (FRIGOTTO, 2016, p.12).

Ao afirmar que devem ser evitadas atividades que entrem em conflito com as convicções morais e religiosas dos pais, o Projeto Escola Sem Partido comete uma de seus maiores equívocos que é a tentativa de impedir o diálogo, o debate e a reflexão sobre as manifestações e comportamentos da sociedade. Quando propõe que professores não "tomem partido" em sala de aula, o Movimento ESP revela desconhecimento da prática dos professores, se apoiando em situações específicas para tentar generalizar comportamentos inadequados.

A insipiência técnica e pedagógica contidas no projeto ESP não deixam dúvidas que se trata de um movimento conservador de uma elite que compreende os riscos que uma sociedade consciente e livre representa à manutenção do seu status quo. Ao propor vigilância aos professores, por meio de denúncias e até filmagens da sala de aula, o projeto coloca as convicções particulares acima do que deve ser coletivo, desconsiderando que não há consenso nem unanimidade nas concepções de mundo e que a educação é, portanto, um direito de todos.

Considerado inconstitucional por diversos órgãos e instituições no Brasil e até fora dele, o Projeto ESP não teve aprovação na maioria dos municípios e Estados aos quais foram submetidos. 
Alguns pareceres importantes merecem destaque: em nota publicada em 22 de julho de 2016, o Ministério Público Federal considerou que o Escola Sem Partido "nasce marcado pela inconstitucionalidade" e "confunde a educação escolar com a fornecida pelos pais". A Advocacia-Geral da União também se posicionou contra o projeto afirmando que a competência para "a elaboração das normas gerais foi atribuída à União” (AGÊNCIA BRASIL, 2016). Para a Procuradoria Geral da República - PGR, a iniciativa subestima a capacidade de discernimento dos estudantes em sala de aula ao considerar que "o alunado seria composto de indivíduos prontos a absorver de forma total, passiva e acrítica a quaisquer concepções ideológicas, religiosas, éticas" (FOLHA DE SÃO PAULO, 2016). Em agosto de 2017, o Conselho Nacional dos Direitos Humanos publicou uma Resolução se posicionando contra a restrição de liberdade e comunicação sobre assuntos da vida política local, nacional e internacional e contra a tentativa de impedir a referência à gênero e sexualidade no combate à discriminação, respeitadas as necessidades e conteúdos apropriados para cada idade.

Em carta enviada ao Estado Brasileiro, o Alto Comissariado da Organização das Nações Unidas denunciou os efeitos do Programa Escola Sem Partido alegando que:

Por não definir o que é doutrinação política e ideológica [...] a proposição permite que quaisquer práticas pedagógicas dos professores sejam consideradas como doutrinação, tornando a escola uma extensão do ambiente doméstico antes de uma instituição educacional que proveja novas perspectivas (UNDIME, 2017).

Em função da retirada dos termos "orientação sexual" e "identidade de gênero" da Base Nacional Comum Curricular, como consequência desses movimentos conservadores, a ONU se posicionou afirmando que a "a discussão sobre gênero e diversidade sexual é fundamental para prevenir estereótipos de gênero e atitudes homofóbicas entre estudantes" (UNDIME, 2017). A pauta do combate à "ideologia de gênero" é uma das principais bandeiras do movimento Escola Sem Partido. 
$\mathrm{Na}$ ocasião da suspensão por inconstitucionalidade da Lei. $\mathrm{N}^{\mathrm{T}} 7.800 / 2016$, referente ao projeto Escola Livre, do Estado de Alagoas, o Ministro do Supremo Tribunal Federal Roberto Barroso afirmou que esse tipo de proposta é "inadequada para alcançar a suposta finalidade a que se destina: a promoção de educação sem 'doutrinação' de qualquer ordem. É tão vaga e genérica que pode se prestar à finalidade inversa: a imposição ideológica e a perseguição dos que dela divergem" (STF, 2017).

Não somente estas instituições jurídicas e políticas se posicionam contrárias ao ESP como também há alguns movimentos compostos por especialistas em educação, professores, estudantes, pais, sociedade civil e organizações sociais. Com isso, observa-se um número maior de opositores ao projeto em comparação aos seus defensores, ocasionando o enfraquecimento da pauta.

Em junho de 2019, o fundador do ESP, Miguel Nagib, declarou à revista Carta Capital (2019) que as atividades do movimento estariam suspensas devido à falta de apoio político, sufocamento financeiro, acúmulo de funções e se disse frustrado com o sumiço do tema nas pautas presidenciais. Em 16 de julho de 2019, na rede social facebook, o Escola Sem Partido informou que, a partir da suspensão do movimento "denúncias, pedidos de socorro e orientação deverão ser dirigidos ao MEC, secretarias de educação, Ministério Público e políticos que se elegeram com a bandeira do ESP'. Enquanto o PL No 193/2016, que tramitava no Senado, foi retirado em novembro de 2017 pelo Senador e autor Magno Malta, o PL 867/2016, que havia sido arquivado em 2018 por falta de consenso, foi desarquivado no início de $2019^{8}$.

Diante do exposto, afirmamos que não é nossa pretensão negar o fato de que professores estão sujeitos a cometer abusos e equívocos no exercício de sua profissão. Todavia, não concordamos

8 O PL n ${ }^{\circ} 867 / 2016$ foi apensado ao projeto 7.180/2014 que consiste em estabelecer que a educação religiosa e moral devem estar de acordo com as convicções dos pais. Dois pontos foram acrescentados pelo recente projeto: o artigo $7^{\circ}$ que garante ao estudante o direito de gravar as aulas e o artigo $8^{\circ}$ que veda participação de grêmios em atividades político-partidária. 
com as incongruências e retrocessos que estão por traz do conservadorismo e das contradições do Movimento Escola Sem Partido. Não obstante, ressaltamos que existem mecanismos de controle social dentro e fora da escola, cuja premissa consiste exatamente na garantia dos direitos de participar democraticamente do processo educacional. Os Conselhos Escolares, os Conselhos Municipais de Educação, os Conselhos Tutelares e as políticas de gestão democrática são exemplos de dispositivos que as famílias podem e devem ter acesso para se inteirar sobre as atividades da escola, desde que para isso, sejam respeitados os direitos de todos e não apenas de uma parcela específica da população.

\section{Educação, ideologia e política}

Iniciaremos este tópico destacando que o conceito de ideologia tem sido utilizado com frequência no país, sobretudo após o contexto das eleições de 2018, quando candidatos de direita utilizaram o discurso da "ideologia de gênero" como um dos pilares de campanha para afirmar a defesa dos "valores da família tradicional brasileira". Por certo, este conceito foi empregado e propagado, inclusive, por quem desconhece o que ele significa.

Ainda que não seja nosso objetivo aprofundar os conceitos de ideologia, interessa-nos, de forma breve e didática, introduzir algumas referências sobre o termo. Em sentido amplo, ideologia se refere a:

Um conjunto de ideias, concepções ou opiniões sobre algum ponto sujeito a discussão [...] Ainda podemos nos referir à ideologia enquanto teoria, no sentido de organização sistemática dos conhecimentos destinados a orientar a ação efetiva. Existe portanto a ideologia de uma escola, que orienta a prática pedagógica; a ideologia religiosa, que dá regras da conduta aos fiéis; a ideologia de um partido político, que estabelece determinada concepção de poder e fornece as diretrizes da ação a seus filiados (ARANHA, 1993, p.36).

De maneira específica, para Marx a ideologia adquire sentido negativo como instrumento de dominação, enquanto para Gramsci 
(1891-1937) a ideologia é uma concepção de mundo que se manifesta na arte, no direito, na atividade econômica e, de modo geral, na vida individual e coletiva (ARANHA, 1993). De acordo com Chauí (2008) a ideologia é constituída como resultado da divisão social de trabalho entre intelectual e material cuja autonomia dos produtores do trabalho intelectual se sobrepõe ao material.

\begin{abstract}
Essas ideias que aparecem como autônomas são as ideias da classe dominante de uma época, e tal autonomia é produzida no momento em que se faz uma separação entre os indivíduos que dominam e as ideias que dominam [...] ideologia é, pois, um instrumento de dominação de classe e, como tal, sua origem é a divisão da sociedade em classes contraditórias e em luta (CHAUÍ, 2008, p.92).
\end{abstract}

Paulo Freire se aproxima do conceito marxista de ideologia para construir sua teoria acerca da educação como ferramenta de transformação social. Ele critica o fatalismo imobilizante do discurso neoliberal que "insiste em convencer-nos de que nada podemos contra a realidade social que, de histórica e cultural, passa a ser ou a virar 'quase natural"' (FREIRE, 2018, p.21). Nesse sentido, Paulo Freire vai provocando uma evolução da sua pedagogia político-pedagógica trazendo "o oprimido como categoria central discursiva e a denúncia da 'desumanização opressora' como caminho político de emancipação” (SCOCUGLIA, 2019, p.110).

Ao se opor a relação entre educação e política, os defensores do Movimento Escola Sem Partido tratam a ideologia como algo a ser rejeitado pela sociedade, defendendo uma suposta neutralidade da escola diante de aspectos sociais, religiosos, culturais e políticos. No entanto, nada está livre da ideologia e pensar dessa forma pode parecer ingênuo. Todavia, talvez este não seja um caso de ingenuidade. Provavelmente o que está sendo defendido é exatamente o a sobreposição de uma ideologia a outra, neste caso, a ideologia dominante e opressora sobre os oprimidos (FRIGOTTO, 2017).

Ora, se toda ação é ideológica, então não existe processo educativo neutro. Nesse sentido, forjar uma neutralidade diante do 
ato educativo significa assumir conivência com a manutenção dos interesses dominantes que assentam na exploração, opressão e alienação dos que estão na base da sociedade.

Creio que nunca precisou o professor progressista estar tão advertido quanto hoje em face da esperteza com que a ideologia dominante insinua a neutralidade da educação. Desse ponto de vista, que é reacionário, o espaço pedagógico, neutro por excelência, é aquele em que se treinam os alunos para práticas apolíticas, como se a maneira humana de estar no mundo fosse ou pudesse ser uma maneira neutra. (FREIRE, 2018, p. 95)

Se não há neutralidade na educação, só podemos dizer que ela é política. E ela "não vira política por causa da decisão deste ou daquele educador. Ela é política” (FREIRE, 2018, p.108). Sua politicidade se dá no diálogo, no debate sobre questões cotidianas, nas manifestações do pensamento e da curiosidade, na descoberta com o outro sobre a vida, os valores, crenças, atitudes e sobre ser humano neste mundo. É através do debate crítico sobre a realidade que o professor, enquanto liderança revolucionária, colabora para a libertação do outro. Libertação que acontece com o outro e não para o outro. Por isto, não deve ocorrer como uma doação, de cima para baixo e nem de fora para dentro. Parte da reflexão verdadeira que, segundo Paulo Freire, precisa conduzir à prática (FREIRE, 1987; 1967). Sendo assim:

A ação política junto aos oprimidos tem de ser, no fundo, "ação cultural para a liberdade", por isto mesmo, ação com eles [...] Não podemos esquecer que a libertação dos oprimidos é libertação dos homens e não das "coisas". Por isto, se não é autolibertação - ninguém se liberta sozinho, também não é libertação de uns feita pelos outros (FREIRE, 1987, p.30).

Depreende-se daí que o professor, como agente fundamental no processo educativo, deve assumir seu papel social, conduzindo processos de reflexão e de tomada de consciência da própria condição humana. Nesse sentido, se posicionar é, portanto, um ato político da mesma forma que não se posicionar também o é. Aliás, de 
que serve a neutralidade do professor? Ou como diria Paulo Freire (2018): "Que é mesmo minha neutralidade senão a maneira cômoda, talvez, mas hipócrita, de esconder minha opção ou meu medo de acusar a injustiça? "Lavar as mãos" em face da opressão é reforçar o poder do opressor, é optar por ele" (FREIRE, 2018, p.109).

Como personagens da ação educativa para a liberdade, professores e alunos devem considerar a práxis como espaço de conscientização e transformação, vencendo a alienação que obscurece os intentos da elite, acostumada a deter privilégios e produzir desigualdades.

Aqueles que tentam argumentar em contrário, afirmando que o educador não pode "fazer política", estão defendendo uma certa política, a política da despolitização. Pelo contrário, se a educação, notadamente a brasileira, sempre ignorou a política, a política nunca ignorou a educação. Não estamos politizando a educação. Ela sempre foi política. Ela sempre esteve a serviço das classes dominantes. Este é um princípio de que parte Paulo Freire. (GADOTTI, 1979, p.06).

A insistência em manter o discurso da suposta neutralidade da educação, corrobora a ideologia da despolitização da massa e garante a perpetuação de uma pedagogia da elite, baseada na alienação e manipulação das classes inferiorizadas em detrimento de seus interesses. A depreciação do legado de Paulo Freire reflete a insistência em negar as páginas obscuras de nossa educação.

As experiências democráticas no Brasil não foram positivas, uma vez que fomos constantemente forçados a baixar a cabeça diante do mandonismo e protecionismo dos paternalistas colonizadores, coronéis, doutores e senhores. A autoridade externa, hospedeira da opressão nos tornou uma sociedade alienada, ingênua e sem esperança (FREIRE, 1967). Nossos modelos de educação e, consequentemente, nossa formação realizou em nós os transplantes e empréstimos de concepções que são o resultado de um não pertencimento, de uma não construção, da negação de nossa capacidade de pensar e construir nosso próprio caminho. $\mathrm{O}$ resultado disso são concepções inoperantes, importadas e alienantes. 
Não obstante, falar em educação sem pensar no seu caráter político e ideológico, utilizando o discurso da neutralidade da escola diante do mundo, é um grande equívoco. No passado, aliás, não tínhamos escolas neutras e sim instituições silenciadas, emudecidas e alienadas, propositalmente, pela elite. Nesse sentido, corroboramos Paulo Freire quando preconiza que é necessário adquirir consciência crítica, politizar-se e revolucionar o ato educativo.

\section{Um Paulo Freire incomoda muita gente}

Considerado o pensador mais importante e influente da história da educação brasileira, o educador pernambucano Paulo Freire é um dos mais respeitados autores do mundo. Sua obra se confunde com sua história de vida, baseada na luta pela transformação social das classes mais populares por meio de métodos de ensino dialógico, centrado na historicidade dos estudantes e nos debates sobre o seu cotidiano, alimentados pela esperança, amorosidade, autonomia, luta, conscientização e liberdade (FREIRE, 1967; 1987; 2018).

Patrono da Educação Brasileira, desde 2012, Paulo Freire teve seu posto ameaçado pelo Presidente da República Jair Bolsonaro que incluiu em seu plano de governo, "expurgar a ideologia de Paulo Freire". Além disso, em abril de 2019, o deputado Heitor Freire (PSL-CE) apresentou o PL N¹930/2019 pedindo a retirada de Paulo Freire do posto de Patrono da Educação Brasileira. Foram apensados a este PL o de N²589/2019, da deputada Federal Caroline de Toni, (PSL-SC) requerendo a retirada da condecoração conferida ao educador brasileiro e o de No3033/2019 substituindo Paulo Freire por José de Anchieta. Nenhuma mudança até a conclusão deste estudo foi feita.

Os motivos para tamanha honraria datam desde a década de 1940, quando começou a implantar suas ideias e projetos de educação transformadora até ser preso pela Ditadura Militar, acusado de "subverter a população" com seu método de "estilo revolucionário" que vinha "comunizando o Nordeste”. Após 72 dias na Delegacia de Segurança Social de Pernambuco, Paulo Freire seguiu para 
o exílio na Bolívia, depois Chile, Estados Unidos, Suiça, Guiné-Bissau e Moçambique e só retornou ao Brasil em 1980. Durante este período, desenvolveu experiências importantes no processo de alfabetização da população adulta, escreveu algumas das suas mais importantes obras e disseminou seu pensamento por diversos países.

A obra e significados de Paulo Freire são imensuráveis para a educação, tanto no Brasil quanto no exterior. Não à toa, é o terceiro autor mais citado do mundo, de acordo com levantamento feito em 2016 pela plataforma Google Scholar'. Diante dos questionamentos sobre a validade de Paulo Freire e suas ideias no Brasil, urge a necessidade de, cada vez mais, nos aprofundarmos, debatermos e expandirmos suas ideias.

À medida que passamos a conhecer a obra de Paulo Freire, ficam evidentes as razões pelas quais ele foi e ainda é perseguido por setores conservadores que dizem combater uma suposta doutrinação ideológica comunista de esquerda. Paulo Freire colabora com a educação brasileira a partir dos pressupostos de conscientização, liberdade e diálogo, de “uma 'ação cultural' em defesa dos oprimidos, um exercício do 'direito ao conhecimento' e um processo de 'ser mais' dos homens e das mulheres" (SCOCUGLIA, 2019, p.18). Para ele, "a educação instrumentalizaria o 'povo emergente mas desorganizado, ingênuo e despreparado', marcado por índices alarmantes de analfabetismo para a construção de uma outra Nação, moderna e mais democrática e liberal" (SCOCUGLIA, 2019, p.51).

A pedagogia de Paulo Freire requisita a busca pela utopia-esperança, mas também pela denúncia-anúncio feita a partir da superação da ingenuidade que aprisiona e apassiva. Ele nos convida não somente à consciência crítica, mas à consciência de classe. Esta, por sua vez, não está em falta apenas nas classes marginalizadas e oprimidas, mas principalmente na classe média que, por ser oprimida, introjeta o desejo de oprimir, atuando como:

9 Disponível em:<https://blogs.lse.ac.uk/impactofsocialscieces/2016/05/12/ what-are-the-most-cited-publications-in-the-social-sciences-according-to-google-scholar/> Acesso em 20 de abril de 2010. 
tropa de elite dos poderosos de plantão. Ela vai tender - do mesmo modo como os ricos fazem com o dinheiro - a perceber o conhecimento valorizado como algo que deve ser exclusivo à sua classe social. Sua participação nos golpes contra as classes populares tem muito a ver, portanto, com estratégias de reprodução de privilégios e muito pouco com moralidade e combate à corrupção (SOUZA, 2019, p. 105-106).

Ocorre que alguns oprimidos "em lugar de buscar a libertação, na luta por ela, tendem a ser opressores também, ou subopressores. A estrutura de seu pensar se encontra condicionada pela contradição vivida na situação concreta, existencial em que se 'formam" (FREIRE, 1987, p.17).

A libertação é, portanto, um processo difícil e que requer permanente busca. Além disso, muitos temem a liberdade porque sua concretização é vista como ameaça. A obra de Paulo Freire entra em contato com o medo que a elite possui de que o oprimido se levante, pois "nenhuma ordem opressora suportaria que os oprimidos todos passassem a dizer: 'Por quê'?” (FREIRE, 1987, p.43). Se o povo que vive imerso, decide emergir, descruza os braços e renuncia a expectação, logo causam pânico na elite. Se desejarem participar e, para isso se conscientizam, os privilegiados inventam uma "teoria da crise" para que possam oferecer a salvação e devolver à população o remédio para sua "enfermidade", restando aos que se impõem ao imobilismo, serem taxados de subversivos e de ameaças à "ordem" (FREIRE, 1967).

A classe opressora tem necessidade da permanência da injustiça e da existência dos oprimidos para que sua "generosidade" se realize. Consideram que a humanização é prerrogativa apenas deles e que qualquer direito à liberdade do outro, sobretudo dos menos assistidos, é subversão. Para Souza (2019) a elite brasileira criou o bode expiatório da corrupção apenas na política para desviar a atenção da opressão que opera em outros espaços e contextos com o apoio da classe média. Esta por sua vez:

não quer só ganhar mais que os pobres. Ela também quer se deliciar com o prazer sádico e covarde que antes era apanágio do senhor de escravos: o 
gozo da humilhação contra quem não tem defesa e precisa aturar calado a piada, o abuso, o insulto, a humilhação sob todas as suas formas. Não é apenas a revolta - mesquinha, mas racional - contra o acesso dos pobres à universidade e por vê-los competir pelo bom emprego. É a raiva também de que o pobre possa usar o mesmo avião e comprar a mesma roupa no mesmo shopping center, ainda que a 24 prestações no cartão de crédito com juros abusivos. É a raiva por perder a empregada, aquela que é abusada de mil formas, e os trabalhadores sem qualificação, aqueles que não têm outra opção senão vender sua força de trabalho a qualquer preço e sob qualquer condição. É desse modo que a escravidão e o ódio ao escravo, agora atualizado como ódio ao pobre, continua no âmago do nosso cotidiano. (SOUZA, 2019, p.263-264).

Como podemos perceber, há um mecanismo de opressão por parte da elite imbuído não apenas da posse do capital econômico, mas também do capital cultural. No caso específico do ESP, o bode expiatório é o professor, apontado como inimigo da sociedade, acusado de doutrinar seus alunos de acordo com as próprias ideologias, cuja imposição atentaria contra os "valores da família". Com isso, criando o caos, convencem as pessoas de que estão defendendo os seus filhos para poder manter o status de protetores da moral e dos bons costumes, enquanto a população não pensa, não discute, não dialoga, terceirizando a sua consciência.

Por ter desenvolvido uma pedagogia dos oprimidos, Paulo Freire só pode ser negado por aqueles que pretendem manter seus privilégios. Seu legado não se resume apenas ao poder de suas palavras, mas a suas ações. Ele foi um educador da práxis que consiste na "reflexão e ação dos homens sobre o mundo para transformá-lo. Sem ela, é impossível a superação da contradição opressor-oprimido" (FREIRE, 1987, p. 21). Além disso, "para dominar, o dominador não tem outro caminho senão negar às massas populares a práxis verdadeira. Negar-lhes o direito de dizer sua palavra, de pensar certo" (FREIRE, 1987, p.71).

A pedagogia freireana está imortalizada na nossa trajetória educacional pregressa e atual. Sua teoria, estudada em universidades e formações de professores em diversos países, está refletida 
nas práticas pedagógicas de milhares de docentes e é reverenciada por diversos setores e organizações sociais. Se um Paulo Freire incomoda muita gente, podemos imaginar a dimensão de suas ideias expandidas e multiplicadas mundo a fora. O caminho da conscientização e da liberdade é sem volta. Uma vez retiradas as amarras e as vendas, é improvável o retrocesso à opressão. Além disso, quem se liberta verdadeiramente, em face de sua humanização, é capaz de, com o outro, provocar revoluções.

\section{Diálogo, consciência, autonomia, liberdade e mudança.}

As ideias de Paulo Freire situam-se no campo progressista e baseiam-se no diálogo, na conscientização, no desenvolvimento da autonomia e conquista da liberdade. Tais premissas pretendem a transformação do homem através da passagem da ingenuidade para a consciência crítica. O diálogo é, talvez, o principal aspecto da sua teoria, pois é a partir dele que a consciência e a liberdade se tornam possíveis. Além de estar na base das relações, o diálogo responsável e comprometido deve servir de espaço para problematização e manifestação da curiosidade. Se é feito de forma vertical, o diálogo se transforma em antidiálogo: não gera criticidade, não é humilde, impõe arrogância, autossuficiência e desesperança,. Nestes casos, o professor não comunica, faz comunicados (FREIRE, 1987). Já o diálogo:

É uma relação horizontal de A com B. Nasce de uma matriz crítica e gera criticidade (Jaspers). Nutre-se do amor, da humildade, da esperança, da fé, da confiança. Por isso, só o diálogo comunica. E quando os dois pólos do diálogo se ligam assim, com amor, com esperança, com fé um no outro, se fazem críticos na busca de algo. Instala-se, então, uma relação de simpatia entre ambos. Só aí há comunicação (FREIRE, 1987, p.107)

Uma das características da falta de diálogo apontadas por Freire é o mutismo. Este, por sua vez, não é a ausência de respostas, mas a falta de criticidade, de consciência revolucionária. Ele defen- 
de que a criticidade esteja associada à curiosidade que mobiliza e conduz à autonomia. Trata-se da passagem da curiosidade ingênua à curiosidade epistemológica (FREIRE, 1987; 2018). Para o educador, "a dialogicidade não nega a validade de momentos explicativos, narrativos, em que o professor expõe ou fala do objeto. $O$ fundamental é que o professor e alunos saibam que a postura deles [...] é dialógica, aberta, curiosa, indagadora e não apassivada, enquanto fala ou enquanto ouve" (FREIRE, 2018, p.83).

$\mathrm{Na}$ medida em que reconhece a especificidade do ato de educar, o professor deve estar consciente da responsabilidade de sua presença e atuação. Por isso, não deve se omitir nem se opor a expressar sua ação política, ação esta que se nega a aceitar as injustiças, o desamor, a desesperança, o desrespeito e a intolerância. Em vez de falar para os alunos, falar com eles. No lugar de lhes ditar ou discursar sobre algo, debater e discutir com eles, afinal, a politicidade nasce do diálogo. Do contrário, as palavras não passam de narrações vazias, verbosidade alienante e alienada. (FREIRE, 1987; 2018). A ausência de diálogo, de expressão do pensamento e de criticidade, no lugar de liberdade, abre espaço para a opressão.

Em relação à liberdade, Paulo Freire diz que ela "amadurece no confronto com outras liberdades, na defesa de seus direitos em face da autoridade dos pais, do professor, do Estado" (FREIRE, 2018, p.103). Tal afirmação reforça que autoridade e liberdade devem caminhar juntas, com o outro e não para o outro. Não pode ser doação, imposição ou convicção prepotente e arrogante. Precisa partir do diálogo amoroso que acolhe, escuta, compreende com humildade.

Se pretendemos a libertação dos homens, não podemos começar por aliená-los ou mantê-los alienados. A libertação autêntica, que é a humanização em processo, não é uma coisa que se deposita nos homens. Não é uma palavra a mais, oca, mitificante. É práxis, que implica na ação e na reflexão dos homens sobre o mundo para transformá-lo (FREIRE, 1987, p.38).

Uma educação para a mudança exige a assunção de uma postura crítica e, acima de tudo, a consciência de si nas relações políticas. 
"Ninguém pode estar no mundo, com o mundo e com os outros de forma neutra" (FREIRE, 2018, p.75). Conforme Paulo Freire:

\begin{abstract}
Não posso ser professor se não percebo cada vez melhor que, por não ser neutra, minha prática exige de mim uma definição. Uma tomada de posição. Decisão. Ruptura. Exige de mim uma escolha entre isso ou aquilo [...] Sou professor a favor da decência contra o despudor, a favor da liberdade contra o autoritarismo, da autoridade contra a licenciosidade, da democracia contra a ditadura de direita ou de esquerda. Sou professor a favor da luta constante contra qualquer forma de discriminação, contra a dominação econômica dos indivíduos ou das classes sociais (FREIRE, 2018, p.100).
\end{abstract}

Nesse sentido, urge romper com a ideia de neutralidade, tendo em vista que este é um discurso de poder tendencioso e opressor que esmaga a liberdade em nome da falsa ideia de que é possível estar no mundo sem se envolver com as questões sociais e políticas. Resultante disso, a prática se converte em omissão, isenção, alienação, descaso. Por isso Paulo Freire nos instiga:

Por que não discutir com os alunos a realidade concreta a que se deva associar a disciplina cujo conteúdo se ensina, a realidade agressiva em que a violência é a constante e a convivência das pessoas é muito maior com a morte do que com a vida? Por que não estabelecer uma "intimidade" entre os saberes curriculares fundamentais aos alunos e a experiência social que eles têm como indivíduos? Por que não discutir as implicações políticas e ideológicas de um tal descaso dos dominantes pelas áreas pobres da cidade? A ética de classe embutida neste descaso? "Porque, dirá um educador reaccionariamente pragmático, a escola não tem nada a ver com isso. A escola não é partido. Ela tem que ensinar os conteúdos, transferi-los aos alunos. Aprendidos, estes operam por si mesmos" (FREIRE, 2018, p.32)

Eis, portanto, o chamado de Paulo Freire a todos os educadores: pensar sobre si e sobre o mundo enquanto sujeito da práxis, reconhecer-se no tecido social e assumir seu lugar de protagonismo diante da opressão que thes nega o direito à dignidade. Não temer a liberdade, denunciar as injustiças, desmascarar a o opressor que 
assenta em falsa bondade, mover-se com o outro e não para o outro, assumir o diálogo como postura, promover a mudança.

\section{Paulo Freire mais forte do que nunca: considerações finais}

As discussões provocadas no contexto das eleições de 2018 trouxeram à tona intensos debates acerca de algumas pautas conservadoras, culminando na ascensão da extrema direita ao poder máximo do país. A polarização política, jamais vista na história recente do Brasil, teve como um dos espaços mais férteis para disseminação de informações, as redes sociais.

Em meio a tudo isso, o Movimento Escola Sem Partido se torna um dos canais de representação das pautas conservadoras, afirmando representar pais e alunos "preocupados com o grau de "contaminação" político-ideológica das escolas brasileiras, em todos os níveis: do ensino básico ao superior"10. Apesar de afirmar que não possui nenhum vínculo político, ideológico ou partidário, o Movimento Escola Sem Partido teve a adesão de apoiadores ligados a políticos da extrema direita, cujas expectativas consistiam na aprovação dos PL No 867/2015 e do PL No 193/2016.

Nesse cenário, as fakes news operaram um vasto esquema de desinformação da população, através da disseminação de vídeos, links e fotos baseadas em inverdades ou distorções da realidade. Além de macular a imagem dos professores perante a sociedade, os defensores do Movimento Escola Sem Partido desabonam Paulo Freire, enxovalhando seu legado cuja principal bandeira é a defesa da educação como ferramenta de conscientização e de luta contra as injustiças. Um pensador que se ocupou exatamente da politização e conscientização através da educação, que desenvolveu uma teoria da práxis libertadora, cujo objetivo consiste na superação da situação opressora pelo próprio oprimido. 10 Disponível em:<https://www.escolasempartido.org/quem-somos/> Acesso
em 18 de abril de 2020 . 
Num país marcado pela exploração das classes trabalhadoras, cujo acesso à educação, cultura, saúde e a outros direitos é basicamente negado ou ofertado de forma insipiente e, considerando que a população marginalizada compreende a base da nossa pirâmide social, é estranho que a elite esteja há tanto tempo no poder. Isso é reflexo de uma sociedade cuja aproximação da política se dá de forma alienada, fragmentada e acrítica. Por isso, qualquer modelo de educação que desperte consciência e ameace estes esquemas de poder, será visto como subversão e atentado contra a "ordem". É por isso que Paulo Freire é rechaçado pelos opressores, bem como pelos oprimidos alienados. Todavia, ele se faz necessário cada vez que surge a tentativa de cercear o pensamento, a livre expressão e as subjetividades que compõem a nossa sociedade.

O Projeto Escola Sem Partido defende exatamente o contrário do que diz combater. É um movimento partidário que se afirma "sem partido". É político e ideológico mesmo quando afirma combater determinadas ideologias. Os partidários do Escola Sem Partido assumem ainda mais as suas contradições ao se aliarem a partidos políticos, fundamentalistas religiosos e à elite conservadora. Desconsideram a pluralidade social e cultural do país ao pensarem em um padrão específico de família, baseada num modelo elitista e classista. Algo do tipo "meu filho, minhas regras" (FRIGOTTO, 2017). Colocam os professores na posição de inimigos das famílias e do país, afirmando que são capazes de doutrinar os alunos com base em seus interesses e convicções pessoais. Com isso, pretendem pôr uma mordaça não apenas no educador, mas na capacidade da escola de contribuir com uma sociedade mais justa, igualitária, crítica e livre.

\section{Referências}

ARANHA, M. L.; MARTINS, M. H. Filosofando: introdução à filosofia. 2.ed. São Paulo: Moderna, 1993.

BRASIL. Constituição (1988). Constituição da República Federativa do Brasil. Brasília: Senado Federal, Coordenação de Edições Técnicas, 2016. 496p. 
BRASIL. Projeto de Lei No 193, de 03 de maio de 2016. Inclui, entre as diretrizes e bases da educação nacional, de que trata a Lei n 9.394, de 20 de dezembro de 1996, o "Programa Escola sem Partido". Brasília, DF. Disponível em: <https:// legis.senado.leg.br/sdleg-getter/documento?dm=569947\&ts=1567535329921\&disposition=inline $>$ Acesso em: 12 abr. 2020.

BRASIL. Projeto de Lei N $N^{\circ}$ 867, de 23 de março de 2015. Inclui, entre as diretrizes e bases da educação nacional, o "Programa Escola sem Partido". Brasília, DF. Disponível em: < https://www.camara.leg.br/proposicoesWeb/fichadetramitacao?idProposicao=1050668> Acesso em: 12 de abr. 2020.

CHAUÍ, Marilena. O que é ideologia. 2.ed. São Paulo: Brasiliense, 2008. (Primeiros Passos, 13).

FREIRE, Paulo. Educação como prática da liberdade. Rio de Janeiro: Paz e Terra, 1967.

FREIRE, Paulo. Educação e mudança. 12.ed. Rio de Janeiro: Paz e Terra, 1979.

FREIRE, Paulo. Pedagogia da autonomia: saberes necessários à prática educativa. Rio de Janeiro/São Paulo: Paz e Terra, 2018.

FREIRE, Paulo. Pedagogia do oprimido. 17.ed. Rio de Janeiro: Paz e Terra, 1987.

FRIGOTTO, Gaudêncio. Escola sem partido: imposição da mordaça aos educadores. e-Mosaicos. v.5, n.9, jul. 2016.

FRIGOTTO, Gaudêncio. Escola “sem” partido: esfinge que ameaça a educação e a sociedade brasileira. Rio de Janeiro: UERJ, LPP, 2017.

GADOT'TI, Moacir. Prefácio de Moacir Gadotti. In: Educação e mudança. $12^{\mathrm{a}}$ ed. Rio de Janeiro: Paz e Terra, 1979.

BRASIL. Ministério da Educação e Cultura. Lei $\mathbf{N}^{\mathbf{0}} \mathbf{9 . 3 9 4}$, de 20 dezembro de 1996. Estabelece as diretrizes e bases da Educação Nacional. Brasília: Senado Federal, Coordenação de Edições Técnicas, 2017. 58p.

SOUZA, Marcele; TOLEDO, Giuliana de. Legado de Paulo Freire é defendido por uns e odiado por outros. Revista Galileu [on-line]. Publicado em 02 de mai. de 2017. Disponível em: < https://revistagalileu.globo.com/Revista/noticia /2017/05/legado-de-paulo-freire-e-defendido-por-uns-e-odiado-por-outros.

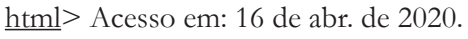


MARX, Karl. O capital. v.1. São Paulo: Boitempo, 2011.

SAVIANI, Demerval. Pedagogia histórico-crítica: primeiras aproximações. 11 ed. rev. Campinas, SP: Autores Associados, 2011.

SCOCUGliA, Afonso Celso. A história das ideias de Paulo Freire e a atual crise de paradigmas. 7.ed. João Pessoa: Editora da UFPB, 2019.

SOUZA, Jessé. A elite do atraso [recurso eletrônico] $1^{\mathrm{a}}$ ed. Rio de Janeiro: Estação Brasil, 2019.

PROFESSORES CONTRA O ESCOLA SEM PARTIDO. Projetos. 2020. Disponível em:<https://www.escolasemmordaca.org.br/?page_id=4218>. Acesso em: 20 de maio de 2020.

MPF diz que Escola Sem Partido é inconstitucional e impede o pluralismo. Agência Brasil. Brasília, 22 de julho de 2016. Educação. Disponível em: < https://agenciabrasil.ebc.com.br/educacao/noticia/2016-07/mpf-diz-que-escola-sem-partido-e-insconstitucional-e-impede-o-pluralismo> Acesso em: 13 de abril de 2020.

PARA PGR, 'escola sem partido' é inconstitucional e subestima alunos. Folha de São Paulo. Brasília, 20 de outubro de 2016. Disponível em: < https://www1. folha.uol.com.br/educacao/ 2016/10/1824785-para-pgr-escola-sem-partido-e-inconstitucional-e-subestima-alunos.shtml> Acesso em: 20 de abril de 2020.

ONU se manifesta contra o "Escola Sem Partido" e cita mudanças na Base Curricular. UNDIME. Brasil, 13 de abril de 2017, Disponível em:<https:/ / undime.org. br/noticia/13-04-2017-14-49-onu-se-manifesta-contra-o-escola-sem-partido-e-cita-mudancas-na-base-curricular> Acesso em: 14 de abril de 2020.

SUSPENSA lei alagoana que instituiu o programa Escola Livre. STF. Brasil, 22 de março de 2017. Disponível em: <http://www.stf.jus.br/portal/cms/verNoticiaDetalhe.asp?idConteudo $=338884>$ Acesso em: 16 de abril de 2020 .

ESCOLA Sem Partido anuncia o fim de suas atividades. Carta Capital [on-line]. Publicado em 19 de julho de 2019. Disponível em: <https://www.cartacapital. com.br/educacao/escola-sem-partido-anuncia-o-fim-de-suas-atividades/> Acesso em: 15 de abril de 2020. 